\title{
PEDAGOGICAL COMPETENCE DEVELOPMENT OF UNIVERSITY TEACHERS WITH NON-EDUCATION BACKGROUND: THE CASE OF A LARGE UNIVERSITY OF EDUCATION IN INDONESIA
}

\author{
Nita Novianti, lyen Nurlaelawati \\ English Education Department, Universitas Pendidikan Indonesia, Bandung, Indonesia
}

nitanoviantiwahyu@upi.edu

First draft received: 31 Dec 2018 Date Accepted: 8 Feb 2019 Final proof received: 27 Feb 2019

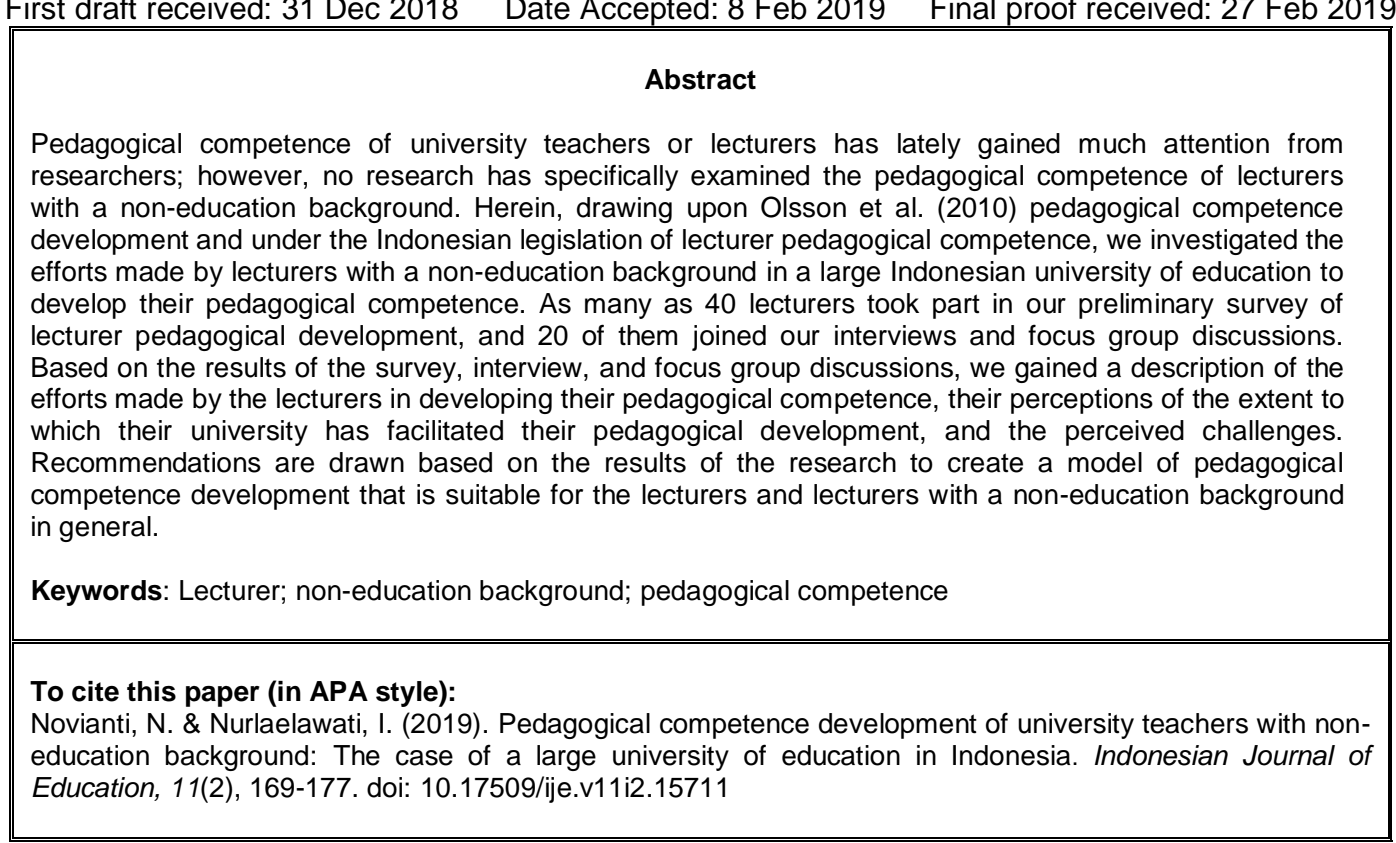

\section{INTRODUCTION}

Unlike teachers, lecturers or teachers at the level of higher education in Indonesia and elsewhere are not required to have a teaching certificate in order to be recruited to teach at the university. Despite this different requirement, both teachers and lecturers are required to have four competencies as stipulated by the Minister of National Education's Regulation No. 16 of 2007. The four competences include pedagogical competence, personal competence, professional competence, and social competence. Consequently, some faculty members do not have any formal training and education on pedagogy. Meanwhile, pedagogical competence is important for a lecturer's career (Merkt, 2017) in addition to research skills.

There has been ample research on the development of lecturers' pedagogical competences with various foci. Muñoz Carril, González Sanmamed, \& Hernández Sellés identified key competences that lecturers should have in teaching in the virtual world, and Cardelle-Elawar \& Nevin (2004) conducted a narrative inquiry into the development of lecturers' pedagogical competence in virtual environment. Spencer (2008) created a model of professional development for lecturers who teach pre-service teachers. Some researchers investigated the establishment of programs for the development of lecturer pedagogical competence (Olatunji, 2013) and whether or not lecturers have taken any formal pedagogical course or training and their opinions of the importance of such course (Aškerc \& Kočar, 2015).

Some other researchers chose to examine lecturers' pedagogical competence based on the assessment done by their students (Yilmaz \& Tinmaz, 2016). A group of researchers also attempted to identify the need for pedagogical training for pre-service lecturers (Robinson \& Hope, 2013; O'Loughlin, Kearns, Laughlin, \& Robinson, 2017)

However, most of the research seemed to treat lecturers with and without education background the same. Meanwhile, lecturers with non-education background certainly lack the formal training and 
education on pedagogy. In addition, most of the research on the need for pedagogical training or education focused on the graduate students, not the teaching or in-service lecturers. To address this gap, we have conducted an investigation on how lecturers with non-education background develop their pedagogical competence. Furthermore, we sought for the lecturers' perceptions of the need for formal pedagogical course or training for lecturers with non-education background.

Pedagogical Competence in the Perspective of Indonesian Legislation

Because the research took place in Indonesia, it is necessary to take into account the country's regulations regarding lecturer pedagogical competence. According to article 28 paragraph 3 point (a), pedagogical competence in the national standards is defined as the ability to manage students' learning which includes understanding the learner; designing, and implementing, learning outcomes; and developing learners to actualize their potential.

Furthermore, as defined by Law number 14 of 2005 concerning Teachers and Lecturers, pedagogic competency entails the ability of teachers and the learning process for students. Regulation of the Minister of National Education number 17 of 2007 summarizes the 10 core potentials that must be possessed by lecturers and teachers that can help with specific lessons, such as the following:

1) Understanding students' physical, moral, spiritual, social, cultural, emotional, and intellectual aspects;
2) Having a good command of learning theory and educational learning principles;

3) Developing a curriculum related to the subjects taught;

4) Carrying out didactic learning;

5) Utilizing information and communication technology for the benefit of learning;

6) Facilitating the development of potential students to actualize their various potentials;

7) Communicating effectively, empathically, and politely with students;

8) Assessing and studying the learning process and results;

9) Utilizing results and evaluations for the benefit of learning; and

10) Making reflective actions to improve the quality of learning.

It is clear then that pedagogical competence is comprehensive, encompassing a teacher's/lecturer's ability in various aspects of teaching and learning that has to be developed in line with the development of time, such as technological advances, scientific revolution, etc.

\section{Pedagogical Competence and Its Development}

To put the present study in a broader context, it is necessary to include and take into account other definitions of pedagogical competence. Olsson, Martensson, and Roxa (2010) have developed a model of pedagogical competence that is practical for this study.

\section{Pedagogical competence - a model}

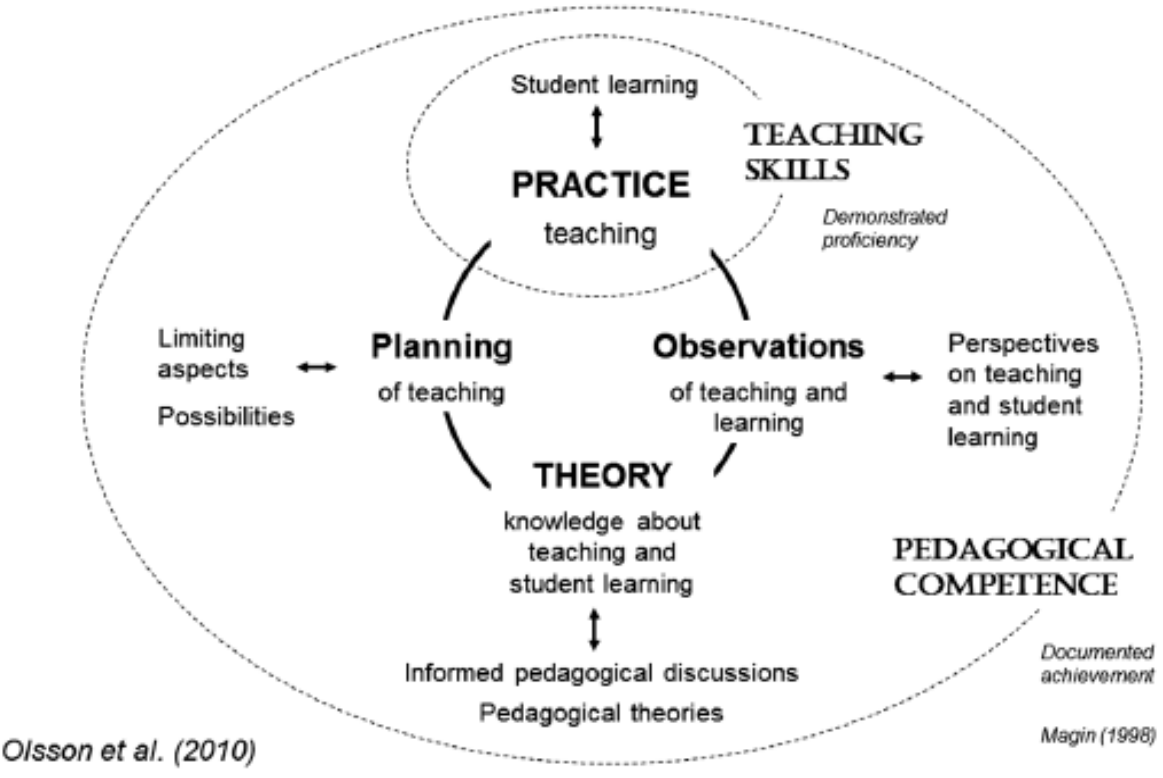

Figure 1: A Model of Pedagogical Competence 
Based on the pedagogical competence model developed by Olsson, Martensson, and Roxa (2010) in Figure 1, it can be understood that pedagogical competence is broader in scope than teaching skills. This great scope of what constitutes pedagogical competence is reflected as well in the Indonesian legislations. The model further shows that teaching skills are part of pedagogical competence, which also involves practices and theories about teaching and understanding of students. Teachers are required to be able to plan and observe the teaching process and ongoing learning. Teachers are also required to understand student learning.

In the context of higher education, according to Merkt (2017), there are at least four dimensions of pedagogical competence development in higher education: personal development; institutional-based development that includes "continuing education and training programs, assessments, and the development of cultural contexts promoting quality" (p. 1); development of "legal and procedural frameworks regarding teacher aptitude in the relevant statutes governing institutions of higher education and the regulations covering professorships, post-doctoral programs and doctoral programs" (p.1); and development of competence-based national standards. Merkt (2017) seems to suggest that stronger frameworks and regulations for the teaching profession in higher education are needed in addition to the commonly practiced personal and institution-facilitated development programs. In addition, standardization at the national level is needed, and Indonesia is heading towards that direction, although admittedly more has to be done in order to meet the goal.

\section{METHOD}

Before conducting rigorous investigation into the case of lecturers' pedagogical development, we distributed a questionnaire to all lecturers with non-education background in the university. The questionnaire consisted of 30 items that identified respondents' age, education background, and length of teaching; respondents' previous experiences of attending formal training on pedagogy; respondents' efforts of developing their pedagogical competence; and their perception of how the institution has facilitated their pedagogical competence development. The questionnaire was developed by adopting that of Mâţă, Cmeciu, and Ghiaţău (2013) with some adjustments based on the Indonesian legislations concerning pedagogical competence and the university in which we were conducting the study.

Out of the 80 questionnaires distributed, only 40 were returned to us, and out of that 40 respondents, only 10 agreed to join a focus group discussion. Based on the results of the questionnaire, we invited the 10 respondents to take part in a focus group discussion in order to further reveal their opinions on pedagogical competence, the need for pedagogical training, and the extent to which the institution has facilitated their pedagogical development. The discussion was also an attempt of finding out the lecturers' perception of their pedagogical competence development.

At the end of the study, we designed a model of pedagogical competence development based on the results of the survey, interview, and focus-group discussion. Our design was also informed by literature review on pedagogical competence development, such as on the techniques or methods to develop lecturer's pedagogical competence based on well-established theories and previous relevant studies.

\section{RESULTS AND DISCUSSION \\ Demographic Information of the Participants}

Based on the demographic survey, $55 \%$ or 22 of the educational non-background lecturers were in the range of $31-35$ years old, and $30 \%$ or 12 of them were $41-45$ years old. The smallest percentage was for the age range of $36-40$ years and $51-55$ years, with $10 \%$ (4 lecturers) and $5 \%$ (2 lecturers), respectively. Because the majority of the non-educational background lecturers were in the range of 31-35 years, it is understandable if most of the lecturer respondents have just obtained a master's or master's degree. Most of the respondents with non-education background or $30(75 \%)$ completed master's degree, and only $10(25 \%)$ of them had taken a doctoral degree. The longest teaching period surveyed was more than twenty years for only one lecturer respondent. Six respondent lecturers (15\%) have taught for $16-20$ years, 8 (eight) lecturers (20\%) have taught for $6-10$ years, and 10 lecturers (25\%) have taught for $6-10$ years. The last category, which is the majority category, is lecturers who have taught for 0-5 years with a total of 14 people (35\%).

In terms of field of expertise, generally the lecturers who participated in this study can be classified into several groups. The first group, which is the majority, is the engineering group (electrical engineering, civil engineering, and aerospace engineering). The second group is language and literature lecturers with a concentration of English, Indonesian, and linguistics. The third group is the economics group (sharia economics, management, and accounting). The fourth group is mathematics and natural sciences (Mathematics and Chemistry). Other groups consist of nursing, welfare education, information science and library study, Islamic studies, and communication science. Thus, it can be said that the respondent lecturers in this study represented almost all faculties at the University.

\section{Development of Pedagogical Competence of the Lecturers with a Non-Education Background}

The research findings in this section focus on how lecturers with non-education backgrounds at the university develop their pedagogical competencies. Factors that contribute to the development of pedagogical competencies of the lecturers were investigated. In general, there are two identified factors, namely internal factors and external factors. Internal factors include initiative, self-motivation, and personal experience. External factors include support from peers, 
senior lecturers, superiors (head of study / cadet / dean / rector) and institutions to develop pedagogical competencies of lecturers with non-educational backgrounds. These factors are explained in more detail below.

\section{Resources for Teaching Knowledge}

Considering that the lecturers of the respondents did not have a formal academic background in the field of pedagogy, it is important to know how they learn to teach and what resources they use to help them in their teaching and learning. Questions in this section require respondents to reflect on the process of obtaining pedagogical knowledge that shapes them to become the teachers they are.

The responses to this question are summarized as follows: more than half of the lecturer respondents $(55 \%)$ or 22 lecturers revealed that they modeled their teaching styles, techniques, and methods after their former lecturers. In other words, they are inspired by how their former lecturers have taught them. Other resources of information for teaching are reading books on how to teach and copying the way other lecturers teach, which is $45 \%$ each. Participating in training is also one of the sources of information that forms the teaching knowledge of the respondent lecturers (40\%). Other sources of information, such as watching videos of lecturers in teaching, improvising themselves, and learning independently helped shape the way they teach.

\section{Participation in Discipline-based Groups and Other Relevant Groups}

The next factor that must be considered in developing lecturer pedagogic competencies is participation in a group of lecturers who share similar field of expertise, commonly abbreviated into KBK in Indonesian. This group usually holds discussions regularly to help each other develop pedagogical competencies of its members. The group is formed at the level of study program, but it is not infrequent for smaller groups of the same field of expertise from different universities gather in both formal and non-formal occasions.

The survey results show that almost all or $90 \%$ of respondents join such groups according to their respective field of expertise. There are only two respondents who do not join such group.

Meanwhile, the lecturers who are members of the field of expertise group, when asked further about how often they participate in group discussions, revealed quite different answers. The highest group meeting frequency, as shown in Figure 9, is a meeting conducted every semester. This frequency is followed by once a month $(27.8 \%)$, and once a year $(16.7 \%)$. The rest answered that they sometimes meet online, but not routinely. Others said it is dependent on the invitation from the leaders of the group, which is uncertain. There were also those who revealed that the field of expertise groups at the university did not actively conduct meetings, so that the lecturer respondents attended the meeting held outside the university quite regularly.

This survey also asks whether the respondent lecturers conduct scientific discussions that can help develop their pedagogical competencies outside the field of expertise groups in their respective departments or study programs.

Almost all or $95 \%$ (38 people) of the respondent lecturers are involved in non-formal scientific discussions in order to develop their pedagogical competencies. The frequency of non-formal discussions varies. More than half of the lecturers reported that they hold the discussion (30\%) monthly and every semester. $15 \%$ of them (6 people) even hold non-formal discussions in order to increase this pedagogical competence for once a week. The rest do informal scientific discussions like this sometimes, if needed, depending on needs, and not necessarily.

\section{Pedagogical Competence Development Involving Peers and Seniors}

For this category, the respondent lecturers were asked about the pedagogical competence development activities that they do, involving peer and senior lecturers. For activities involving peer lecturers, the question is whether the lecturers observe the teaching and learning of another lecturer to learn how to teach. The results show that $70 \%$ or 28 respondents make observations of the teaching and learning processes in other lecturers' classes to help develop their pedagogical competencies.

Half $(50 \%$ or 20$)$ of the lecturers who make observations in other lecturers' classes revealed that they carry out this activity every semester. Further interviews revealed that they do this to renew their pedagogical knowledge and skills each semester. In addition to developing pedagogical competence involving peer lecturers, we also asked whether they do any pedagogic competence development activities involving senior lecturers.

More than half of the respondent lecturers (55\%, 22) said that they are paired to teach with a senior lecturer, or as a teaching assistant, and $92.3 \%$ of the lecturers who serve as teaching assistants felt the effectiveness of the arrangement in helping to develop their pedagogical competence.

Further investigation revealed what these senior lecturers have done that the respondents perceived to be useful in helping them develop their pedagogical competence. According to the respondent lecturers, senior lecturers are especially effective in helping them develop material and manage the class; giving input on teaching methods and techniques; creating apperception techniques; using learning models, managing teaching materials/syllabus/course unit/ RPS; giving examples and inspiration about things that are good and not good in teaching, so that the lecturers can avoid mistakes that senior lecturers might make; giving direction in teaching; providing additional knowledge about the disciplines studied; providing in-depth knowledge in the field of their expertise; helping 
evaluate the way the respondent lecturers teach to then be discussed and given input for development.

\section{Pedagogical Competence Development Activities by Study Programs/Departments/Institutions}

The study program, department, or institution where the respondent lecturers work at must certainly contribute to the development of the pedagogical competence of the lecturers. Therefore, the next question in the survey looks at the extent of the role of study programs, departments, or university in facilitating the development of pedagogical competence of their lecturers.

The responses of the respondent lecturers to this question are quite varied compared to the same answer for other pedagogic development-related activities. More than half $(55 \%$, or 11 people) said they did not take part in training in pedagogical competence development held at the level of study program/department/faculty/university. After further investigation, this lack of participation was not due to the reluctance of the respondent's lecturers, but because the institutions did not provide any pedagogical competence development training.

For less than half of the respondents $(45 \%, 18)$ who participated in pedagogical competence development training at the level of study program/department/faculty/university, many of them attend this kind of training every semester $(38.5 \%)$, the rest $(30.8 \%)$ do it once a year. Meanwhile, other respondents revealed that such training has never been held in the place where they work.

We also explored whether the respondent lecturers attend workshops or seminars that can help them develop their pedagogical competence. The responses show that as many as $65 \%$ or 26 lecturers have attended workshops or seminars, and the rest have not. When asked about the reasons underlying their participation, some cited their own initiative or encouragement from other parties, such as colleagues or study program/department, and others. The answers from the respondent lecturers are quite diverse. Almost all or $62.5 \%$ of respondents participated in this activity on their own initiative. Others, namely $18.8 \%$ and $12.5 \%$ attended workshops or seminars on the development of pedagogical competence at the encouragement of the head of study program/department/faculty/university and co-workers.

\section{Respondents' Perceptions of their Pedagogical Competence Development}

Next, we investigated the perceptions of the respondent lecturers of the factors that support the development of pedagogical competence. We started by asking the lecturers about their perceptions of the effectiveness of several activities in helping develop pedagogical competencies using a Likert scale (Strongly Agree, Agree, Neutral, Disagree, Strongly Disagree).

The responses to this cluster of questions indicate that almost all the respondent lecturers $(95 \%)$ agreed that the activities mentioned in the questionnaire helped them in developing their pedagogical competencies. We also investigated the perceptions of the respondent lecturers on the importance of training to develop their pedagogical competencies in several fields. Again according to almost all respondent lecturers $(90 \%)$, the activities that most need special training included making syllabus/learning planning, followed by preparing learning material (75\%), conducting selfevaluation and student learning and communicating with students (each 60\%), thesis proposal defense, and student academic guidance (50\%). The activity which according to the perceptions of the respondent needs special training the least is the thesis proposal defense, which is only chosen by 6 lecturers (15\%).

Finally, we asked the perceptions of the respondent lecturers on the efforts made by the study program/department/faculty/university where they work in helping develop their pedagogical competencies. The findings show that $65 \%$ of the respondent lecturers felt that the study program/department/faculty/university has facilitated the development of their pedagogical competencies. Unfortunately, $35 \%$ of the respondent lecturers or 14 of them felt this was not the case. Of the $65 \%$ of respondents who felt the institutions they work at has helped in the development of their pedagogical competence, cited the following types of assistance: providing opportunities for training or seminars, motivating to continue their studies; hold curriculum and SAP preparation / renewal workshops; organize lesson study; provide information about related trainings; provide assistance in the form of material or training; help the program increase the capacity and professionalism of lecturers; preparing facilities; input for evaluating students; and make teaching materials.

\section{Input from Respondent Lecturers for the Institution: Proposed Model of Pedagogic Competence and Discussion of the Results}

Finally, we investigated the expectations of the respondent lecturers for the institution at which they work in terms of their pedagogical competence development. This is really important, as the end goal of this study is to formulate a model of pedagogical competence suitable for lecturers with a non-education background.

Based on the results of the interview and focus group discussion, we found that the lecturers hope that the institution where they work at can help their pedagogical competence development by holding training, seminars, and workshops; holding intensive training and providing the opportunity to get a short course, especially in different universities, to learn the best and most up-to-date teaching techniques and methods for non-educational courses; facilitating the exchange of teachers to faculties/study programs/other universities both in/outside the country and internships at domestic or foreign institutions in an effort to develop practical knowledge that can later be shared with other lecturers and students; providing good and inspiring examples; providing support, both in the form of financial assistance to attend pedagogical competence training; explaining the direction of the curriculum; 
organizing training of learning models; providing good infrastructure and resource persons in their fields; and providing funds to participate in pedagogical competence training outside their university.

Before discussing the pedagogical competence development model that we have designed based on the results of the survey, interview, and focus group discussion, it is important to discuss the results in light of the context of the study and in comparison to those of relevant studies.

One of the results of this study shows that a similar trend in university recruitment for teachers is found as well in UK universities (Spencer, 2008). In Spencer's and our studies, we both found that while the universities regularly conduct induction or orientation process for newly recruited lecturers, no "Initial Teacher Training" is offered. In our study in particular, the induction mostly focuses on the procedural knowledge and general regulations of working in the university, not offering any training on the teaching and learning process that the lecturers will conduct.

The result of our study also corresponds to that of Aškerc and Kočar (2015) in Slovenian context. Similar to their study, we found that almost all of the lecturers perceived the need for particular training or education on pedagogy, but only a small number of the lecturers have actually obtained such training or education.

Another issue to highlight is related to the status of the university as an institution for teacher training and education. As mentioned previously, the study was conducted to lecturers with a non-education background in a large state university dedicated to education and teaching and learning in general. Although the lecturers participating in this study agreed that their peers and seniors have greatly helped their pedagogical competence development in a way that they provide the lecturers with good examples and good advice, it should be underlined here that the respondents did not feel that the institution where they work at has sufficiently facilitated their pedagogical competence development. This is certainly an irony since the university is dedicated to the education and training of pre-service teachers, yet the university's own lecturers do not perceive the university to have provided them the appropriate education and training needed for their pedagogical competence development.

One possible reason why pedagogical competence of university teachers has not been given proper attention is that their career development is still primarily determined by their research achievements, especially for non-education universities (Madhavaram \& Laverie, 2010; Merkt, 2017). It is rather surprising then to find that the same phenomenon can also be observed in education universities as well.

Hence, education universities and the university under study in particular should start paying more attention to the lecturers that they have recruited, especially those who have no background in education, to make sure the best quality of education is delivered to students by its teaching staff, regardless of the academic background. Partly in this light we then created a model of pedagogical development that may be suitable for the case of our study.

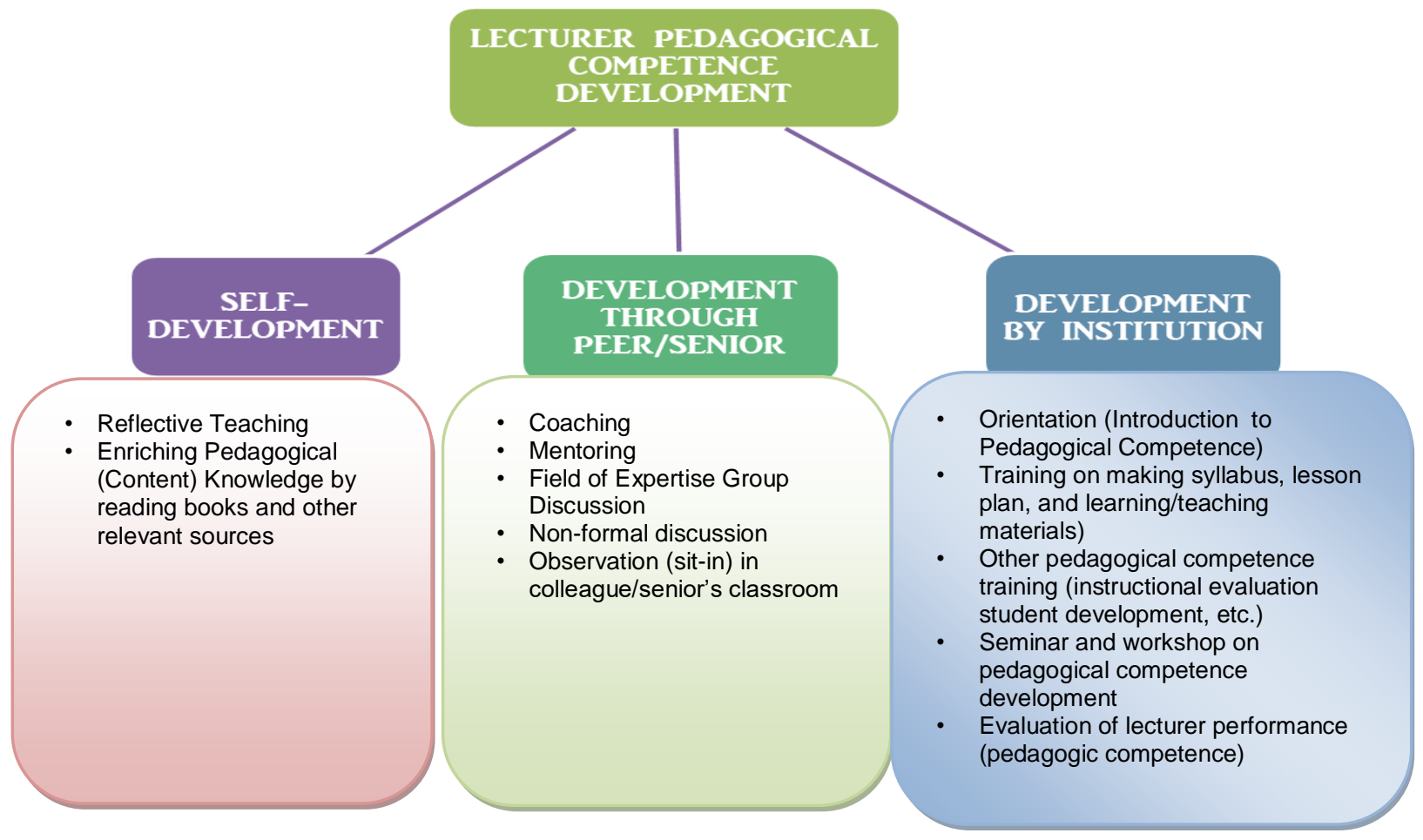

Figure 2: A Model of Pedagogical Competence Development of Non-Education Lecturers 
The Pedagogical Competence Development Model of Non-Education Lecturers as shown in Figure 2 can be described as follows. The development of noneducational lecturers' pedagogical competence can be divided into three forms, namely the development of pedagogic competence by the lecturers themselves, development of pedagogic competence with colleagues and senior lecturers, and development of pedagogical competence by institutions (university/faculty/ department/study program). These three forms of development must be mutually sustainable and carried out continuously throughout the academic career of the lecturers.

The development of pedagogical competence of lecturers can be started from themselves, both before and after being appointed as a lecturer. This selfdevelopment can be done through activities called reflective teaching. Reflection on teaching can be done by various methods, and one that is considered most appropriate is reflective journal or reflection carried out by recording the results of reflection in a diary or journal. Reflective journals do not have a consistent definition because researchers use different terms for reflective journals (Maarof, 2007). Some people might refer to it as study notes, diaries, dialogue journals, or personal narratives (see Maarof, 2007). Some others might say that reflective journals are a way of telling experiences and events chronologically (Wellington, 2000, in Majid, 2008) and for building intellectual and affective skills in which authors explore their experiences to develop new understanding and appreciation (Boud et al., 1985, in Le \& Le, 2007). In addition, of course lecturers can always enrich their pedagogical knowledge by reading various relevant sources, including accessing sources of information about other pedagogies, such as the internet.

The next form of development involves the role of a colleague or senior lecturer. Some types of activities that can be carried out are by joining the field of expertise groups and other discussion groups, holding non-formal discussions with other lecturers regarding pedagogy. Especially for development involving senior lecturers, guidance can be made by pairing new lecturers and senior lecturers, so that new lecturers can learn from the senior lecturers. The next method of development is mentoring. Teacher mentoring is initially a program that is designed to help prospective teacher students before they enter the realm of teaching (Morrison et al., 2009). However, now teacher mentoring is not only aimed at prospective teachers, but also teachers or teaching staff who have long taught, known as veteran teachers (Ganser, 1996; Koki, 1997).

The teacher mentoring definition is quite diverse, as the term used to refer to this activity also varies. Yee (2016), for example, uses the term peer coaching, there are also those who use the term peer mentoring, and some call it teacher peer mentoring. In essence, mentoring is:

A nurturing activity, where they are more skilled or experienced in teaching, supporting, encouraging, and advising those who are less skilled or less experienced in teaching with the aim of increasing professionalism and / or personal development. (Anderson \& Shannon, 1988, p. 40).

Teacher mentoring is thus carried out by fellow teachers who have the knowledge, skills, and most importantly different experiences.

Teacher mentoring has been widely applied in various settings, especially schools, because of its enormous benefits. According to Huling and Resta (2001), some of these benefits include: 1) Can help improve professional competence; 2) Providing space for reflection that is very important for teachers to be able to recognize weaknesses or weaknesses in the teaching process so far and strive to improve or improve the quality of teaching; 3) Renewal in teaching knowledge and skills; 4) Psychological benefits, such as increased self-confidence; 5) Collaboration, namely improving good relations between teachers; 6) Contributions to leadership.

The third form of development of lecturer pedagogical competence is development involving the institution. As with other forms of development, institutional development must be carried out periodically and continuously. It starts with the orientation process of lecturers who have a noneducation background before starting to teach. The orientation process should be carried out at the study program level, with emphasis on technical matters, such as how to prepare a course unit or syllabus and lesson plan, how to prepare material for lessons, and so on.

In accordance with the survey results, many lecturers with a non-education background conveyed the need for special training in how to evaluate student learning and evaluate self-learning and observe student development. Therefore, special training needs to be carried out which can also be in the form of workshops that can help lecturers with their pedagogical competence. Pedagogical training courses or PTCs have indeed been considered important by university teaching staff around the world, including in Slovenia (Veniger, 2016). To enrich and renew the pedagogical knowledge of lecturers, institutions are also advised to send lecturers to relevant seminars. Facilitation from institutions is needed by lecturers, both in the form of non-material and material support, especially in terms of infrastructure.

Equally important from the lecturer pedagogical competence development model is periodic evaluation conducted by the institution. This evaluation can serve as a monitoring of the development of lecturer pedagogic competence as well as to measure the success of the pedagogical competence development programs that have been carried out by the institution.

\section{CONCLUSIONS}

In this research we have attempted to find out how lecturers with a non-education background develop their pedagogical competence. The perceptions of the lecturers of the efforts to develop pedagogic competence made by the institution were explored, so 
that a model for developing pedagogical competence could be developed. The survey results were followed by interview and focus group discussion, and the overall results were then used as the basis to develop a pedagogical competence development model that is proposed to be applied at the university under study, in particular, and other institutions or universities in general hiring lecturers with a non-education background.

In general, the competence development model takes three forms of development, namely selfdevelopment, development with senior colleagues or lecturers, and development by institutions. These three forms of development must work together and be carried out continuously. The model has not been pilottested, though, and we plan to do so in the near future. Other researchers are welcome to test the model in their respective contexts.

Finally, it is important to note that our study had limited amount of respondents, and was only conducted in one university. Hence, future studies on the same topic should include more respondents from several universities for more generalizable results.

\section{REFERENCES}

Anderson, E. M., \& Shannon, A. L. (1988). Toward a conceptualization of mentoring. Journal of Teacher Education, 39(1), 38-42.

Aškerc, K., \& Kočar, S. (2015). Teaching and the pedagogical training of university teaching staffpractice and opinions under Slovenian higher education legislation. Education Inquiry, 6(2), 159175.

Cardelle-Elawar, M., \& Nevin, A. (2003). Developing pedagogical competence in online environments: $\mathrm{A}$ narrative inquiry of faculty development in higher education. A paper presented at The Society of for Integration of Technology and Education, Albuquerque, New Mexico.

Ganser, T (1996). Preparing mentors of beginning teachers: An overview for staff developers. Journal of Staff Development, 17(4), 8-11.

Huling, L., \& Resta, V. (2001). Teacher mentoring as professional development. ERIC Digest, 1-6.

Koki, S. (1997). The role of teacher mentoring in educational reform. Pacific Resources for Education and Learning, 1-6.

Le, T. \& Le, Q. 2007. Reflective learning in online communication. Dalam J. Sigafoos \& V. Green (Ed.). Technology and teaching. New York: Nova Science Publishers, Inc.

Lee, I. (2008). Fostering preservice reflection through response journal. Teacher Education Quarterly, Winter, 117-139.

Maarof, N. (2007). Telling his or her story through reflective journals. International Education Journal, 8(1), 205- 220

Majid, F. A. (2008). The Use of Reflective Journals in Outcome-Based Education during the Teaching Practicum. Malaysian Journal of ELT Research, 4, 32-42. Diperoleh dari www.melta.org.my.
Madhavaram, S., \& Laverie, D. A. (2010). Developing pedagogical competence: Issues and implications for marketing education. Journal of Marketing Education, 32(2), 197-213. https://doi.org/10.1177/0273475309360162

Mâţă, L., Cmeciu, D., \& Ghiaţău, R. M. (2013). A reference framework of pedagogical competences of language teachers in the initial training programmes. Procedia-Social and Behavioral Sciences, 93, 648-653. https://doi.org/10.1016/j.sbspro.2013.09.255

Merkt, M. (2017). The importance of academic teaching competence for the career development of university teachers: A comment from higher education pedagogy. GMS Journal for Medical Education 2017, 34(4), 1-4.

Morrison, A., Chorba, K., Korbar, K., \& Greve, K. (2009). Relational learning: Peer mentoring among teacher candidates. Mid-Western Educational Research Association.

Muñoz Carril, P. C., González Sanmamed, M., \& Hernández Sellés, N. (2013). Pedagogical roles and competencies of university teachers practicing in the e-learning environment. The International Review of Research in Open and Distributed Learning, $\quad 14(3)$, 462-487. https://doi.org/10.19173/irrodl.v14i3.1477

O'Loughlin, V. D., Kearns, K., Sherwood-Laughlin, C., \& Robinson, J. M. (2017). How do we train our future faculty to teach? A multidisciplinary comparison of graduate level pedagogy courses offered at a large Midwestern university. College Teaching, 65(4), 172-181.

Olatunji, M. O. (2013). Ensuring and promoting the pedagogical competence of university lecturers in Africa. Journal of Educational and Instructional Studies, 3(3), article 12.

Olsson, T., Martensson, K., \& Roxa, T. (2010). Pedagogical competence-A development perspective from Lund University. In Ryegard, A., Apelgreen, K., \& Olsson, T. (2010). A Swedish perspective on pedagogical competence. Division for Development of Teaching and Learning. Uppsala University.

Robinson, T. E., \& Hope W. C. (2013). Teaching in higher education: Is there a need for training in pedagogy in graduate degree programs? Research in Higher Education Journal, 21, 1-11.

Spencer, C. (2008). Teacher educator, go educate thyself: Who teaches the teachers of teachers? Establishing a model of professional formation for teacher educators in further education colleges. A paper presented in the proceedings of ATEE: Further development of teacher educators' pedagogical competence chaired by Raukiene, A., \& Žogla, H. I, 714-720.

Veniger, K. A. (2016). University teachers' opinions about higher education pedagogical training courses in Slovenia. CEPS Journal, 6(4), 141-161.

Williams, J. (2012). Using CoRes to develop the pedagogical content knowledge (PCK) of early 
career science and technology teachers. Journal of Technology Education, 24(1), 34-53.

Yee, L. Q. (2016). Peer coaching for improvement of teaching and learning. JIRA, 6(1), 64-70.
Yilmaz, H. B., \& Tinmaz, K. (2016). Students' view about pedagogical competence of lecturers. Journal of Higher Education and Science, 6(2), 209-219. 